virov, po katerih poznamo stoiško filozofsko predajo. To pomanjkanje je zlasti hudo, če se obravnavajo vprašanja, o katerih celo med pripadniki stoiške šole ni bilo soglasja, in pojma, ki je delal težave tudi tistim antičnim piscem, ki nam poročajo o stoiških naukih. Da bi se izognila enostranski ali prenagljeni razlagi tega tako težko opredeljivega pojma, se mu je približala s treh strani: s strani dialektike, $s$ strani spoznavne teorije in $s$ strani fizike. V sintezi, ki jo avtorica podaja na koncu, si prizadeva dati oris pojma lekton $\mathrm{z}$ več strani in mu podati obrise glede na sorodne pojme, tako rekoč od zunaj. Ob koncu nam avtorica kaže pot, po kateri bi lahko prišli do sinteze tega v stoiški filozofiji tako večplastnega pojma. V njej ima pomembno vlogo trojica signifiant - signifié - chose, na kateri temelji de Saussurejeva teorija znaka in ki jo Coseriu v svoji Zgodovini filozofije jezika enači z znano stoiško trojnostjo. Tu bi lahko pripomnili, da je de Saussurova knjiga Tečaj splošnega jezikoslovja pač izdaja zapiskov, ki so jih uredili študenti sami, zato morda niti ni rečeno, da si je hotel de Saussure na predavanjih lastiti pravico do odkritja trojice označeno - označujoče - stvar. ${ }^{3}$

Knjiga Jezik v filozofiji starih Grkov je nadvse dobrodošla kot prikaz samostojne raziskave in kot zbirka zanimivih odgovorov na pomembna vprašanja, a tudi kot spodbuda za nadaljnje raziskave in objave na tem področju, nepogrešljivem za popolno predstavo o antičnem umu in pogledu na jezik.

3 Če drugega ne, je bila tudi v marsikateri ženevski knjižnici na razpolago znamenita Stein thalova Zgodovina jezikoslovja pri Grkih in Rimljanih, v kateri so stoiški nazori o tem razloženi dovolj jasno.
Prepričani smo, da se bo tako o poj$\mathrm{mu} \lambda \varepsilon x \tau$ óv kot o položaju jezika $\mathrm{v}$ stoiški filozofiji pri nas še precej govorilo in pisalo. Razprava se šele začenja.

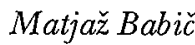

\section{BERNARD BORTOLUSSI: BESCHERELLE GRAMMAIRE DU LATIN}

Paris 1999, Hatier

Ocena

Bescherellova Slounica latinskega jezika (La grammaire du latin) je po besedah samega avtorja (Bernard Bortolussi) napisana tako za začetnike kot za že izurjene latiniste. Prvim so namenjeni predvsem poglavje o naglasu in izgovarjavi, shematičen prikaz oblikoslovja in skladnje ter slovnične preglednice z oblikami. Pri poglavju o izgovarjavi je avtor razlagi k posameznim glasovom dodal kratek, a zanimiv prikaz razvoja latinske pisave. Iz razlage in zgledov je razvidno, da gre za pravila ponovno uveljavljene izgovarjave klasičnega obdobja (pronuntiatio restituta), čeprav manjkajo ravno zgledi za glasove, pri katerih se klasična izgovarjava razlikuje od tradicionalne (c pred svetlima samoglasnikoma, $s$ med samoglasnikoma ipd.).

Sledi standardni prikaz oblikoslovja s sklanjanjem zgledov in naštevanjem izjem, pri čemer bo marsikomu tuja (in za spoznanje manj praktična) delitev tretje deklinacije na sedem tipov (tip mare, tip flumen ...), ki ne upošteva razporeditve po samostalniških deblih. Ker je slovnica namenjena $v$ prvi vrsti francoskemu bralcu, je poglavju o morfologiji dodan poseben uvod $\mathrm{z}$ razlago funkcij posameznih 
sklonov. Že v začetnih poglavjih se pojavljajo zgledi v povedih, ki so vse vzete iz originalnih latinskih besedil in prevedene. Ob citirani povedi sta voklepaju vedno navedena tudi avtor in mesto dela, iz katerega je vzeta, kar je lahko zelo koristen didaktični pripomoček za učitelja, če uporablja kak drug učbenik.

Skladnja je obravnavana $v$ dveh poglavjih, prvo (La syntaxe) je posvečeno podrobni obravnavi skladnje sklonov, podredju in priredju, ki je še posebej natančno obdelano tudi s stilističnega vidika. Paragrafi, ki so namenjeni podredju, prinašajo delitev odvisnikov na vsebinske (complétives),pod te spadajo tudi infinitivni konstrukciji akuzativa in nominativa $\mathrm{z}$ infinitivom ter vsi odvisniki povedne in želelne vsebine - oziralne (relatives) in prislovne (circonstantielles). Čeprav je ta delitev manj pregledna, je veliko bolj točna od običajnega prikaza v slovenskih slovnicah, ki latinske odvisnike povezujejo včasih glede na veznike in včasih glede na vsebino. Drugi del, ki bi ga v slovenskih slovnicah prav tako našli med poglavji o sintaksi, nosi naslov Slovnica povedi in besedila (La grammaire de l'énoncé et du texte) in skuša preseči slovnične okvire stavka, tako da ga obravnava znotraj besedila, pri tem pa se avtor opira tudi na dognanja sodobnega jezikoslovja. $\mathrm{V}$ tem se kaže tendenca francoske šole, ki se pri branju in interpretaciji antičnih besedil še posebej posveča besedilni analizi odlomka. Tako se pri iskanju koherence in kohezije obravnava tudi raba zaimkov in prislovov, predvsem pa raba naklonov, zlasti konjunktiva ( $\mathrm{v}$ neodvisnih stavkih in $\mathrm{v}$ odvisnikih v sosledici časov) in njegovih posebnosti (modalna atrakcija, absolutna raba ipd.). Nekoliko nerodna stran te delitve poglavja o skladnji je, da prvi del prinaša obravnavo vseh tipov odvisnikov, tudi tistih, ki zahtevajo rabo konjunktiva, šele $v$ drugem delu pa so predstavljeni pravila te rabe in sosledica časov.

Za frankofonega slovenskega bralca je slovnica uporaben pripomoček za utrjevanje na višji stopnji, ko ima že dovolj znanja jezika, da ga ne zmedeta drugačni slovnična metoda in terminologija. Iz istih razlogov je lahko slov-. nica uporaben didaktični pripomoček za učitelje latinščine, da svojo metodo po potrebi prilagodijo ali spremenijo.

Sonja Capuder

\section{SOFOKLES:}

\section{AJANT - TRAHINKE - FILOKTET.}

Prevod in komentar: Kajetan Gantar in Brane Senegačnik. Spremna beseda: Brane Senegačnik. Založba Obzorja, zbirka Iz antičnega sueta (32). Maribor 2000. 240 strani.

Recenzija

Pred leti je kolegica, ki je takrat ravno srečno opravila diplomski izpit, priredila nekakšno filološko zabavo $\mathrm{v}$ pregnantnem, čudaškem pomenu te besede. Sedeli smo okrog mize in se smejali resničnim in izmišljenim zgodbam o članih izpitne komisije, medtem ko je iz zvočnikov donel radijski intervju $z$ enim izmed njih, s Kajetanom Gantarjem; slavljenka ga je nekaj prej po naključju ujela v etru, ga posnela na kaseto in jo shranila, očitno posebej za to priložnost. Čeprav ni te nenavadne godbe takrat nihče posebej pozorno poslušal, se še vedno dobro spominjam odgovora na značilno suho novinarsko vprašanje o željah in pričakovanjih glede prihod- 